\title{
"Unless she gives better satisfaction": Teachers, Protestant Education, and Community in Rural Quebec, Lochaber and Gore District, 1863-1945 ${ }^{1}$
}

\author{
Mary Anne Poutanen
}

This study explores the complex relationships from 1863 to 1945 between the Board of School Trustees of Lochaber and Gore, its teachers, and parents, to reveal how these different parties influenced, resisted, and consented to changes in local schooling. Thus, the analysis moves away from a social control model which has dominated the literature on schooling in Quebec to reveal the local dynamics at work in the community. The Protestants of Lochaber and Gore were a microcosm of the larger Protestant community in Quebec. All of the problems associated with rural education in poor regions across Quebec, such as teacher transiency, widespread poverty and a modest tax base, the primitive nature of one-room schoolhouses, and conflict between the seasonal demands of agriculture and school time, existed here. This investigation is based on historical documents from the Archives of the Western Quebec School Board in addition to newspaper accounts and local histories.

Cette étude explore les relations complexes existant entre les maîtres, les parents et les commissaires d'école des cantons de Lochaber et de Gore, afin de montrer comment ces différents acteurs participèrent, résistèrent et consentirent aux changements scolaires dans leur localité. Ainsi, l'analyse se dissocie du modèle de contrôle social qui a dominé l’historiographie de la scolarisation au Québec pour mettre en lumière le jeu des dynamiques locales. Les protestants de Lochaber et de Gore furent un microcosme de la communauté protestante du Québec. Tous les problèmes reliés à l'éducation dans les régions rurales pauvres de l'ensemble du Québec s’y retrouvaient : le caractère éphémère des maîtres, la pauvreté généralisée et le bas taux de taxes foncières, le caractère primitif des écoles à une seule classe et le conflit entre les exigences saisonnières de l'agriculture et l'école. Cette recherche, qui porte sur la période 1863-1945, s’appuie sur les documents tirés des Archives du Western Quebec School Board ainsi que sur les journaux et les monographies locales.

In November 1922, the parents of pupils who attended the Lochaber Bay School complained to school board trustees that their children were unruly at school. They held the teacher, Miss M,

1 This study is made possible thanks to funding by the Foundation for the Advancement of Protestant Education in Canada. I would like to thank the anonymous readers for their astute comments and my colleague Roderick MacLeod for his critique of this paper and for the map which he designed.

(CHistorical Studies in Education / Revue d'histoire de l'éducation 15, 2 (2003): 237-72 
responsible for their sons' and daughters' refractory behaviour, citing her inability to keep the usual school hours, supervise her students, and carry out all of her teaching obligations. After deliberating about this grievance at a regularly scheduled school board meeting, the trustees authorized the secretary-treasurer to notify Miss $M$ that her services would no longer be required after December $31^{\text {st }}$ "unless she gives better satisfaction than she has done in the past months." He instructed her to open the school at 9 a.m., give only two 15-minute recesses and a one-hour lunch break, keep the children on the school grounds, prevent them from damaging property, follow the curriculum, and supervise and correct her pupils' spelling mistakes. ${ }^{2}$ From the school board's point of view, the prospect of having to hire a suitable replacement before the new school term began in January was a formidable task. We know nothing about what Miss M thought about her teaching appointment since she, like so many who passed briefly through the four Lochaber and Gore Protestant schools, left no surviving written records.

The purpose of this study is to explore the nature of the relationships of the Anglo-Protestant community of Lochaber and Gore with its schools, school board, teachers, and to a lesser extent with the provincial government, in order to understand their involvement in the local education of children. It will show how these different parties - exemplified by Miss M, Lochaber Bay parents, and school board trustees - influenced, resisted, and consented to changes at the local schoolhouse. Such a focus will also clarify what importance parents placed on educating their children, what they understood constituted a good Protestant education, and their assessment of local schooling. The Protestants of Lochaber and Gore were both a minority who operated a dissentient school board and a microcosm of the larger Protestant community in Quebec. Thus, the analysis moves from a socialcontrol model which has dominated the literature on schooling in Quebec to one that reveals the local dynamics at work in the community.

Until recently, Quebec historians of education have overemphasized the role played by the state in the province's system of schooling, resulting in research that was periodized by government legislation and presented from the perspective of state initiatives and its concomitant administration. These scholars relied upon

2 Archives of the Western Quebec School Board (hereafter AWQSB), Box 6, File 6.9, Minutes of the Board of School Trustees of Lochaber and Gore, 24 Nov. 1922. 
government-generated documents, such as superintendents' and inspectors' reports, but without a countervailing view they have been predisposed to adopt similar critical attitudes as these education officials toward poor rural communities and their school boards. Preoccupied as they were with the development of the bureaucratic state, historians did not challenge this "top-down" or social control model, which presupposed that schooling was imposed on an unwilling population. Thus, the local community and its contribution to schooling was disregarded. ${ }^{3}$ In a 1997 review of the historiography, Jean-Pierre Charland argued for a refocusing of research on local reactions to public education in Quebec similar to the academic work of historians of Ontario education. ${ }^{4}$

The social control model has also dominated the scholarship of Ontario schooling. Alison Prentice, a pioneer in the history of education, contends that a system of schooling was imposed upon an unwilling and apathetic population who resisted state education. ${ }^{5}$ In a later publication which she co-authored with Susan Houston, Prentice has not modified her position. Both authors argue that a state system of education did not usher in an era of popular

3 Louis-Philippe Audet's influential work on education is a case in point. Based on records such as the superintendents' and inspectors' reports, minutes of the Council of Public Instruction, Journal of Public Instruction, debates of the House of Assembly, and commissioned reports on the status of education, his reading of education tends to reflect the negative view of education officials. Parents were perceived as lacking interest in their children's education, teachers were deemed unqualified, and school commissioners were criticized for being inept and uneducated themselves or more interested in balancing their books than in local education. See for example, Le système scolaire de la Province de Québec, vol. 1-6 (Quebec: Les Éditions de l’Érable, 1950-1956); Educateurs: parents, maîtres (Québec: Editions de l'action,1963); and Histoire du Conseil de l'instruction publique de la province de Québec, 1856 -1964 (Montreal: Editions Leméac, 1964). Audet's view of history has been a dominant force in the historiography and his legacy has influenced a generation of historians who have focused on the development of a public system of education without paying close attention to what was taking place at the local level. Others, influenced by the view of French structuralists that education systems were a means to reproduce social relations, continued this "top-down" approach. The work by historians Nadia Fahmy-Eid and Micheline Dumont in the 1980s concentrated on identifying the strategies of the dominant classes to indoctrinate school systems with their ideologies while not exploring popular resistance to those strategies and the role of local communities in determining the form and content of education in their schoolhouses. See their Maîtresses de maison et maîtresses d'école: femmes, famille et éducation dans l'histoire du Québec (Montréal: Boréal, 1983); and Les couventines: l'éducation des filles au Québec dans les congregations religieuses enseignantes, 1840-1860 (Montréal: Boréal, 1986).

4 Jean-Pierre Charland, “L'Histoire de l'éducation au Québec regard sur la production recente," RHAF 50, 4 (1997): 599-614.

5 Alison Prentice, The School Promoters: Education and Social Class in MidNineteenth Century Upper Canada (Toronto: McClelland \& Stewart, 1977). 
education; school promoters were faced with "a giant job of salesmanship" ${ }^{6}$ to get a reluctant population on board. With fewer alternatives open to them, communities were enticed by government funds to establish state schools; parents were dragged into a system they did not value. Similarly, Bruce Curtis maintains that a bourgeois system of education was imposed on a population which had only two options, either to accept or resist it. ${ }^{7}$ That parents influenced and supported aspects of the system of schooling while resisting those parts with which they disagreed is not considered. In contrast, R.D. Gidney, D.A. Lawr, and W.P.J. Millar's studies reveal that communities influenced school policy by opposing the efforts of state officials to enact policies they did not favour, thus forcing bureaucrats to modify their decisions. ${ }^{8}$

A new generation of Quebec historians focuses on schooling at the community level. ${ }^{9}$ Andrée Dufour explores the beginning of public education in Quebec and the relationship between the state and local rural communities in developing a system of schools and demonstrates that the rural population was strongly implicated in education. $^{10}$ To understand the contributions made by both the state and rural communities to provide children with an education, she suggests that historians must study the interaction between these two entities. I would add that a crucial subset of interactions also occurred at the community level between the school board, teachers, and parents. J.I. Little has written extensively on early

6 Susan Houston and Alison Prentice, Schooling and Scholars in Nineteenth-Century Ontario (Toronto: University of Toronto Press, 1988): 338.

7 Bruce Curtis, Building the Educational State: Canada West, 1836-1871 (London, Ont.: The Althouse Press, 1988), 372.

8 D.A. Lawr and R.D. Gidney, "Who Ran the Schools? Local Influence on Education Policy in Nineteenth-Century Ontario,” Ontario History 72, 3 (1980): 131-43; and R.D. Gidney and W.P.J. Millar, "From Voluntarism to State Schooling: The Creation of the Public School System in Ontario,” Canadian Historical Review (CHR) 6, 4 (1985): 44373.

9 See for example, Jean-Pierre Charland, L'entreprise éducative au Québec, 18401900 (Ste-Foy: Presses de l'Université Laval, 2000). While not directly challenging the social control model, Charland makes the local community a focus in a chapter wherein he analyzes the complex nature of the relationship between communities and their school commissioners. He emphasizes the democratic nature, at least in theory, of school board elections. Using minutes of school board meetings, Charland details commissioners' responsibilities and how they dealt with criticisms from their constituencies, but does not explore the complex community inter-actions. Similarly, Robert Gagnon underscores the democratization of teaching, the link between the social demands of education and the workings of the school commission, but does not inquire into the relationships between students, teachers, and parents; Robert Gagnon, Histoire de la Commission des écoles catholiques de Montréal (Montreal: Boréal,1996).

10 Andrée Dufour, Tous à l'école: Etat, communautés rurales et scolarisation au Québec de 1826 à 1859 (Ville Lasalle: Hurtubise HMH, 1996), 22. 
local education in the Eastern Townships. His exploration of the Scottish and French-Canadian populations of Winslow, for example, shows how they initiated and supported local education despite their difficulty in raising adequate funds to pay for schooling and the government's refusal to adequately finance education. ${ }^{11}$ Similarly, Wendie Nelson's examination of the "Guerre des Eteignoirs” reveals how the population of St-Grégoire protested the growing burden of school taxes. The local elite, out of self interest, did not want to support a public system of education in which its own children did not participate; the habitants feared the loss of local control over schooling and the growing influence and power of the village elite. ${ }^{12}$

This investigation, as part of a more comprehensive history of Protestant education in Quebec, uses documents of the Archives of the Western Quebec School Board - minutes of school board meetings, petitions, correspondence, teachers' journals, trustees' reports, inspectors' comments, and school censuses - in conjunction with newspaper accounts, local histories, superintendents' reports, and petitions and letters sent to the superintendent of education in Quebec City. The study is framed by the creation of the Lochaber and Gore dissentient school board in 1863 and by the end of the second world war following the introduction of compulsory education in 1943 but before education officials advocated for school board consolidation in the post-war period. This periodization allows the teasing out of the rather involved interactions between the community and its local schools without adding complex regional issues which county boards often engendered. The school municipality of Lochaber and Gore is an ideal subject for analysis: all of the problems associated with rural education in poor regions across Quebec (teacher transiency, widespread poverty of its ratepayers with its concomitant modest tax base, and the primitive nature of one-room schoolhouses) existed here; the Anglo-Protestant population was small, which

11 See "Education and Local Government," in J.I. Little, Crofters and Habitants: Settler Society, Economy, and Culture in a Quebec Township, 1848-1881 (Montreal: McGillQueen's University Press, 1991), 219-45; "School Reform and Community Control in the 1840s: A Case Study from the Eastern Townships,” Historical Studies in Education 9, 2 (1997); "'Labouring in a Great Cause': Marcus Child as Pioneer School Inspector in Lower Canada’s Eastern Townships, 1852-59,” Historical Studies in Education 10, 1-2 (1998); and "The Demise of Voluntarism: School Reform to 1846," in J.I. Little, State and Society in Transition: The Politics of Institutional Reform in the Eastern Townships 1838-1852 (Montreal: McGill-Queen’s University Press, 1997), 171-201.

12 Wendie Nelson, “'Rage against the Dying of the Light': Interpreting the Guerre des Eteignoirs,” CHR 81, 4 (2000): 551-81. 
facilitates a more manageable study; and the minutes of the school board meetings are complete. Therefore, this microstudy of Lochaber and Gore has much broader implications for rural Quebec.

In the discussion that follows, I explore the demographic, social, and economic developments which characterized Lochaber and Gore over an eighty-year period. Next, I analyze the convoluted and sometimes paradoxical associations between the school trustees, the teachers, and the community. To do this, I examine how poverty affected the financing of local schooling by way of teachers' salaries, working and learning conditions at Lochaber and Gore schools, teacher transiency, teachers' competence, and community support for its schools - as well as the relationships at the schoolhouse.

\section{The Township of Lochaber and Gore}

Lochaber and Gore was located on the north shore of the Ottawa River 19 miles downstream from Hull and just east of Petite-Nation, now St-André Avellin (see Figure 1). The township's first settlers arrived here from Lochaber, Scotland at the beginning of the nineteenth century to farm 110 square miles of land acquired by popular native son, Archibald MacMillan, and his associates. ${ }^{13}$ The timber trade, originally conceived of as a means to support pioneer farming, provided the motor for the region's economic development. From the onset, insufficient arable land thwarted whatever aspirations of self-sufficiency Scottish settlers had, nor could it sustain the level of agronomical success that some local farmers managed to squeeze out of the soil. ${ }^{14}$ By necessity, inhabitants combined agriculture with work in the lumber trade, usually spending winter months in shanties away from their families. The poor soil and rocky terrain meant that many of the farmers converted their land to rough pasture to raise livestock, rather than grow crops, and to keep dairy farms which supplied milk to local butter and cheese factories. These industries flourished in the southern part of the township, in Lochaber Bay,

13 Chad Gaffield et al., History of the Outaouais (Québec: Institut québécois de recherche sur la culture, 1997), 126.

14 Ibid., 141. 
provisioning the local economy and logging camps. ${ }^{15}$ The household economy of this farming community depended upon all family members to ensure economic survival. While the men worked in the lumbering trade, the women were left to manage the farms; children were called upon to assist their mothers in the heavy task of animal husbandry, just as they were expected to work with their fathers during the planting season and at harvest.

Settlers, composed primarily of Scots and to a lesser extent of English and Irish, established their own Protestant institutions Presbyterian, Baptist, Methodist, and Anglican churches, societies, and schools - early on. Like their counterparts elsewhere, local Scots, who valued the ability to read and discuss the bible, built schoolhouses in the early decades following settlement. ${ }^{16}$ By the 1840s, settlers had erected a school in Lochaber Bay. Rev. John King reported preaching at the school which he travelled to from his home in Clarence village. ${ }^{17}$ Even the more remote area of the school district, Silver Creek, boasted a log schoolhouse which had been built in the 1840s conveniently situated between two main county roads where local women taught. ${ }^{18}$ While the entire populace of the township was never very large, ${ }^{19}$ the AngloProtestant population declined from 70 per cent of the total in 1851, falling sharply after 1881 , to 30 per cent by 1941 . In the same year, in the largest centre of the district, Thurso, the citizenry had burgeoned threefold since the turn of the century. The town's majority francophone population comprised 85 per cent of the total census of 1,295; the remaining 15 per cent included English, Scottish, Irish (14 per cent), and German ( 1 per cent). ${ }^{20}$ These

15 Farm values uncover differentiation in Papineau County: the most highly valued farms were located in the south of the county, where farms in 1941 averaged $\$ 6,775$; farms in the centre of the county were estimated at $\$ 4,964$; and further north, at $\$ 3,234$ (ibid., 319).

16 See Little's discussion of Winslow in the Eastern Townships in Crofters and Habitants, 220. Kathleen H. Brown's study of early-nineteenth-century Stanstead schooling reveals the enormous efforts made by township settlers to provide their children with a rudimentary education. Early on they erected rough schoolhouses and hired teachers: Schooling in the Clearings: Stanstead 1800-1850 (Stanstead: Stanstead Historical Society, 2001), 173.

17 Angus Campbell MacLachlan, Lochaber Bay, My Well Loved Country Home (1999), 19.

18 Willard Vandine Smith, Silver Creek: The Centre of the World (Wawa, Ont: Friesens, 2001), 44; and AWQSB, School Journal, 1943-44.

19 The population grew very slowly from a total of 1,307 people in 1851, to 2,765 in 1881, and by 1941, 3,014 residents.

20 Enoch Padolsky and Ian Pringle, A Historical Source Book for the Ottawa Valley (Ottawa: Linguistic Survey of the Ottawa Valley, Carleton University, 1981), 376-79. 
changing demographic characteristics paralleled economic transformations in the region.

By the late1920s, agriculture in the region was in decline and farming eventually became a part-time occupation for many who were transformed into factory and urban workers, ${ }^{21}$ further afield in industrial cities or close to home in Thurso at its Singer sewingmachine factory. ${ }^{22}$ The town had historically serviced the rural population with its stores, post office, sawmill, churches, and schools. The arrival of the railroad meant that residents of the township could shop in Thurso for goods they had previously sought elsewhere. In this way, Thurso replaced Ottawa, Hull, and Montreal as a vital commercial centre for the local population. ${ }^{23}$ It also became a manufacturing hub which drew upon the lumber and agricultural products of the hinterland and served the population as a marketplace. ${ }^{24}$ With fewer local job opportunities and to avoid the harsh life that indigenous farming practices encompassed, young women formed the bulk of the population who chose to work as maids and factory hands in Thurso and in nearby towns. ${ }^{25}$ Many of the men and women who left the region maintained links to the community by visiting family and friends, attending Lochaber Bay's Old Boy Reunions, and responding to appeals made by church and cemetery committees for financial assistance. Others returned to teach in the same schools where they had received their early education.

\section{School Trustees, Teachers, and Parents}

The relationships between school trustees, teachers, and parents were complex, ambiguous, and sometimes difficult. Their lives intersected intimately, both at work and at leisure: they shared households, attended local churches, joined a variety of social, cultural, and agricultural associations which promoted community interests, and participated in civic and social events. Because of the close proximity of their lives, school trustees, parents, and teachers had to be sensitive to potential flashpoints of

21 Harry Turay, "The Process of Settlement and Land Clearance in Papineau County, Quebec, 1800-1967” (M.A. thesis, University of Ottawa,1969), 65.

22 Gaffield et al., History of the Outaouais, 283.

23 Turay, The Process of Settlement, 28.

24 Ibid., 53.

25 Gaffield et al., History of the Outaouais, 335-36. 
conflict by responding effectively to reduce tensions and by being open to the opinions of others. School trustees had to reconcile contentious views about financing local schooling - from setting the mill rate, calculating the school board budget, which had to be affordable to ratepayers, and paying teachers' salaries, to choosing textbooks - and about teaching methods, community expectations, and implementing bureaucratic regulations. Teachers were vulnerable to community politics. Their position required ingenious skill in asserting themselves without alienating their students, parents, and trustees and in emphasizing those characteristics which they held in common, be it their rural origins or their Anglo-Protestant identity.

It was in their institutions, especially at church and at school, where the Protestant identity was fortified. In the face of a declining population, the Protestant community became more protective of preserving its character. In 1863, a group of Protestant dissenters broke from the existing school board, which had become increasingly Catholic and therefore no longer reflected their interests. They formed a new school board, holding its first meeting in Thurso at the home of timber baron John A. Cameron. ${ }^{26}$ A year later, trustees opened a school in Thurso Village in the old Presbyterian church. Others followed. These newly established Protestant schools symbolized the importance that the community placed on education, the determination and the efforts it had made, and the generosity of individual farmers who consented to or offered to have the schoolhouses built on a section of their farm land.

One was located on the farm of the late Mr. William Lamb on the hill north of Lochaber CPR station and another on the farm of Mr. Rory McLachlan, with the third school, known as "MacDonald's School” situated some distance west. The last school in Lochaber was on the McEachern Farm. ${ }^{27}$

For many of these benefactors, their link to the establishment of a local schoolhouse - two schools by Confederation and two more by 1880 - and to the scholarly achievements of the students was a source of enormous pride.

26 AWQSB, Box 6.8, File 6.1, Minutes, 22 Aug. 1864.

27 Gatineau Protestant Teachers' Association Centenary Display, History of Education in the Gatineau Valley (1964), 35. 


\section{School Trustees}

Elected by fellow citizens, school trustees volunteered their time and energy to the education of local children and to ensure that their schooling was grounded in the precepts of Protestantism; thus, they played a key role in preserving community identity. Particular class and religious affiliations characterized the men who were elected school trustees. An examination of the Lochaber and Gore school board reveals that trustees usually were members of the local elite: some were professionals, such as Baptist minister Archibald Campbell or clerk George Edwards; many more were merchants, such as George William Cameron and W.C. Edwards, both of whom were involved in the timber trade, and Hugh McLean; a few were artisans, such as tinsmith and tavern-keeper James L. Gray, who became a merchant years later; but the majority were farmers. They came from farming families with long-standing roots in the community and which contributed several generations of trustees - Alexander and Hugh McLean, Robert, Peter, and Adelbert MacLachlan, ${ }^{28}$ and Duncan and James McCallum, to name a few - over the period under study. They derived status in the community in part as members of the original Scottish settler families. They were, as historian Jean-Pierre Charland points out, the most prosperous in the farming community given the property requirements a trustee had to meet in order to qualify for the office. ${ }^{29}$ Many of the trustees were Baptists. Their various responsibilities at church forged friendships and interest and involvement in local schooling. The first chairman of the school board, Alexander McLean, embodied these characteristics: he was a merchant, came from one of the founding farming families of Lochaber and Gore, and was a Baptist. Many were involved in the executive of local associations such as the Lochaber Bay Cemetery Committee, ${ }^{30}$ the Agriculture Society, and the local Cheese Farmers' Association which in 1904 elected P.M. McLachlan as one of its three directors. ${ }^{31}$ Similarly, their wives

28 A.P. MacLaughlan's 250-acre farm, three-quarters of which was tillable land and the remaining woods, was located close to the local school, cheese factory, station, and church and only a mile from the highway between Buckingham and Thurso. The barn could accommodate fifty head of dairy cattle. The ten-room "modern" farmhouse boasted hardwood floors, furnace, toilet, and lavatory: see Buckingham Post, 21 June 1930.

29 Charland, L'entreprise éducative au Québec, 184.

30 For instance, J.C. MacCallum was elected vice-president of the committee in 1913 while serving as chairman of the school board: Buckingham Post, 5 Dec. 1913.

31 Ibid., 5 May 1905. 
served on the executive of associations which included the Women's Christian Temperance Union, Red Cross, and Women's Institute. Mrs. A.P. MacLachlan, for instance, was active in all three clubs: she was elected first vice-president of the Red Cross in 1916; ${ }^{32}$ hosted meetings of the WCTU at her home; ${ }^{33}$ and presided over the 1937 election of the Women's Institute executive, and was herself chosen head of its immigration committee. ${ }^{34}$ As members of the local elite, trustees were well positioned to impose their values and authority on the Anglo-Protestant citizens of Lochaber and Gore. Yet, they negotiated this power with members of the community who exercised their own pressure and influence. They were, according to Little, "agents of state power and influence at the local level" on the one hand, and "represented the interests and desires of their electors" on the other. ${ }^{35}$

School trustees are often portrayed in the historiography as fiscally driven, conservative, and prominent men of the local community, more interested in balancing the books than in bestowing a good education upon local children. This view fails to take into consideration that the school board had to harmonize the demands of the provincial government, personified by the district school inspectors, of the teachers, who were difficult to recruit and replace, and of the parents, who were their neighbours and relatives and who pressured trustees to keep education costs down. The trustees were responsible for the same four rural schoolhouses throughout the period under study, which speaks to both the tenacity of the community to remain in the region and to the intention of the school board to provide their constituency with educational facilities close at hand. They rejected creating a single township school and conveying pupils to it, opting for schooling which reflected the local needs of its constituency. Schools in the south of the township, in Lochaber Bay and Thurso, served a denser, more prosperous population compared to those further north, in Gore of Lochaber and Silver Creek, where the farms were poorer and more scattered. The disparities notwithstanding, each family felt an affinity to its neighbourhood school. ${ }^{36}$

The school board's primary responsibilities were to establish and maintain its schools, hire teachers, provide basic tools such as

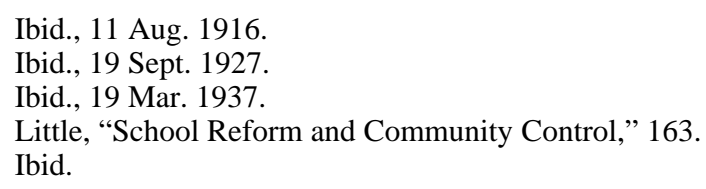


textbooks, blackboards, and maps needed in the classroom to promote teaching and learning, and to set the mill rate to pay the cost of local schooling. These trustees, like their counterparts elsewhere in the province, searched for creative measures, as Little argues, to provide schooling to their constituency within the parameters of deficient government funding and rural poverty. ${ }^{37}$ The school board's austere budget was derived from the community's modest resources, which made up the largest proportion -80 per cent of the budget came from school taxes and school fees - and the meagre government grants that contributed the remainder. ${ }^{38}$ Since the government's share was fixed, the only way to augment the board's budget was to increase the mill rate, which would have further encumbered the poorer members of its constituency. Many eked out a humble living on farms characterized by substandard soil suitable only for pasturage.

Veteran Outaouais school inspector Bolton McGrath knew his district very well, having travelled its width and breadth for thirtyfive years. Yet, while acknowledging the relationship between widespread poverty and inferior schools, contending that only prosperity could raise the standards of local education, ${ }^{39}$ he failed to appreciate the antipathy of the school board to increasing the burden of school taxes on impoverished ratepayers. McGrath and his colleagues accused trustees of relying upon the government to bail them out through grants rather than raise the mill rate. The trustees' caution was characteristic of poor rural regions across Canada, as Jean Cochrane explains:

They were not remote politicians, meeting in some downtown boardroom. They were neighbours and parents, who held their meetings in the school, which many of them had attended...Every cent they spent beyond their government grants came right out of their neighbours' pockets, and in cashshort rural areas, they made sure it was necessary before they raised a tax. ${ }^{40}$

37 Little, Crofters and Habitants, 235.

38 Paul-André Linteau, René Durocher, and Jean-Claude Robert, Histoire du Québec contemporaine: De la Confédération à la crise (1867-1929) (Montreal: Boréal, 1979), 244.

39 Inspector's Report to the Minister of Public Instruction, 1878-79.

40 Jean Cochrane, The One-Room School in Canada (Toronto: Fitzhenry \& Whiteside, 1981), 142. 
Similarly, when school taxes were in arrears, Lochaber and Gore trustees were particularly reticent to force a member of the community to sell his homestead in order to pay delinquent taxes. Minute books reveal that derelict ratepayers were given additional time to pay their tax bills before trustees initiated a series of warnings and interventions which culminated in the odd threat or cajolery to induce them to settle their debts. Trustees rarely served distress warrants against debtors' goods and chattels although in 1892 they did act against Donald McLean in the Circuit Court to collect outstanding school taxes. ${ }^{41}$ Since education in Quebec was not free, trustees charged parents an additional monthly fee for each of their children - Protestant and Catholic alike - attending their schools. Parents struggled to pay this added charge and when some of them fell behind in their monthly payments, the secretarytreasurer pursued them to clear the debt or threatened to ban their children from school until the arrears were paid. The school board absolved families of this obligation under exceptional circumstances such as extreme poverty, widowhood, when husbands and fathers were serving overseas during the two world wars, and during the Great Depression.

Teachers' salaries made up a large part of the school board budget. Trustees formally negotiated hiring contracts with teachers around issues such as income, boarding, time off to attend professional meetings and conferences, exemptions from school fees for their children, and holidays. In an effort to keep these costs in check, trustees searched for and hired teachers who were willing to work for lower wages than those offered by urban and more affluent rural school boards, especially those close to Montreal where salaries had to compete with an urban scale. While the school boards ideally sought experienced, qualified teachers those who held advanced elementary or model school certificates, or normal school diplomas - by advertising in newspapers, consulting with the district school inspector for his recommendations, and corresponding directly with Macdonald College for recruits, they usually hired young, inexperienced, and often unqualified female teachers. Since school boards paid women teachers lower salaries than their male counterparts, the Lochaber and Gore trustees hired few male teachers over the period under study, which served as a cost-cutting measure. Moreover, like poor rural school boards around the province, trustees regularly

41 AWQSB, Box 6, File 6.8, Minutes, 16 July 1892. 
replaced teachers at the end of their contracts with lower-paid teachers to avoid salary increases. Most of those offered reengagements refused to renew their contracts. Teachers often came from outside the region and thus were unfamiliar either with teaching and living in the countryside or with the specific township. A consequence of this high teacher turnover was the school board's difficulty in providing a coherent education to the community's children. School inspector J.W. McOuat understood the repercussions of repeated teacher changes in the classrooms:

The frequent change of teachers has gone against the success of the school work as no less than four have been in charge since September. The pupils are well-meaning and earnest and seem ready to do their work but the grading has become badly mixed. I have advised the teacher, as to the best way to improve these conditions and I expect that will be well in the near future. ${ }^{42}$

The school board's inability to offer teachers decent salaries served to rationalize their dependence upon unqualified female teachers whom they could remunerate with smaller wages. ${ }^{43}$ The percentage of qualified teachers working in Papineau County Protestant schools never exceeded 58 per cent. ${ }^{44}$

Teacher shortages, social and economic changes related to the depressions of the 1870s and 1930s, international political events such as the two world wars, and growing pressure from teachers' organizations $\mathrm{s}^{45}$ and the provincial government wreaked havoc with the school board's budget and influenced how much the trustees would remunerate their teachers. In its first decade of existence,

42 AWQSB, Box 23, File 23.13, Lochaber \& Gore Permanent Record, Public Schools, Province of Quebec, 1920-1951, 25 Apr. 1937.

43 For instance, in the late 1870s teachers' salaries in the Lochaber and Gore schools ranged from $\$ 12$ to $\$ 23$ a month. By the twentieth century, the gap narrowed. When a teacher resigned suddenly in March 1923, trustees were unwilling to pay her replacement more than \$46 a month, unless the teacher had a diploma (AWQSB, Box 6, File 6.9, Minutes, 19 Mar. 1923). That same year the school board offered teachers $\$ 500$ for a tenmonth term. By the early 1930s the school board paid qualified teachers $\$ 50$ monthly and unqualified teachers \$45: ibid., 28 Sept. 1931.

44 Gaffield et al., History of the Outaouais, 370.

45 A local history of the Provincial Association of Protestant Teachers shows that teachers of the Gatineau and nearby districts organized a local branch of the association, the Gatineau District Local Association, on October 26, 1929. While membership was open to all teachers and inspectors in the district, it was not until 1945 when participation became compulsory: The Gatineau Protestant Teachers’ Association Centenary Display, History of Education in the Gatineau Valley, 1. 
the board paid teachers between $\$ 20$ and $\$ 30$ per month, and by the 1870 s and in the throes of a depression, trustees could hire a teacher such as Miss Laura D for \$15 a month. ${ }^{46}$ At the start of the new term in 1889, the trustees set out their budget regarding teacher salaries. They would offer the Thurso schoolteacher a maximum of $\$ 40$ a month for a ten-month term and the remaining three other teachers not more than $\$ 18$ a month. While the salary gap reflected in large part the higher status that trustees accorded the Thurso school and thus the need to hire a qualified teacher, it also spoke to the number of pupils each teacher had in her classroom and the trustees' use of untrained teachers. ${ }^{47}$ As I have already pointed out, class differences paralleled the geographic stratification of the township. For this reason, the trustees, themselves members of the local elite, were inclined to place the qualified teachers in the south.

The board had to pay its teachers higher salaries during province-wide teacher shortages such as in wartime. During the Great War, trustees offered Miss Kerr \$375 per annum to teach at the Gore of Lochaber school. If she refused their offer, trustees were prepared to increase it to $\$ 425$ as well as give her charge of the more coveted Thurso Village school. ${ }^{48}$ Throughout the Second World War, the board sought permission from the inspector to advertise for teachers in Ontario, owing to a scarcity in Quebec. ${ }^{49}$ The 1920s was another period when school boards throughout Quebec scrambled to fill teaching positions. Lochaber and Gore trustees refused to accept Miss Cleland's resignation until they knew precisely why she wanted to quit the school. If she was leaving on account of her salary, they argued, then they were prepared to increase it from $\$ 600$ to $\$ 650 .^{50}$ Not all of the teachers were successful however when requesting a raise in salary, as the following convoluted negotiations between another Miss $\mathrm{C}$ and the board demonstrate. When she asked for an increase in her remuneration before the expiration of her contract, the board responded by firing her and started to search for another teacher who could begin work in January. A week later, they rescinded this edict, reconsidered her request for a raise, and offered her \$5 more a month. Three days later, they learned that a male teacher

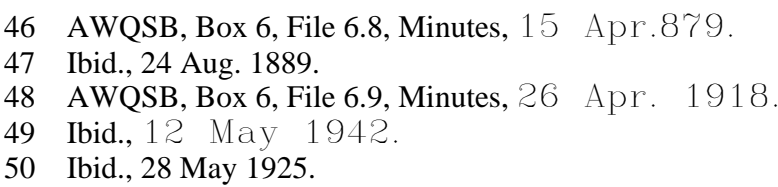


would accept the teaching position if the trustees agreed to pay him a higher salary than Miss $C$ had demanded. The board accepted Miss C's sought-after resignation and hired Mr. M. Four months later, when Mr. M demanded an increase in his salary if he was to stay for the next term, the trustees refused to renew his contract and advertised for another teacher at the same salary they had originally offered him. ${ }^{51}$ Even though they were willing to pay more for a male teacher, there was a limit to the margin of manoeuvrability they had with respect to salary negotiations and it would seem that Mr. M. had breached it along with the school board's patience.

Under certain other circumstances, trustees showed some flexibility by conceding higher wages or specific changes in hiring contracts to teachers who were in a position to demand more remuneration or personal preferences. For instance, immediately following the Protestant community's declaration of dissent in 1863 and in the flush of idealized objectives to establish good district schools, including a model school in Thurso, trustees granted Miss Cairns' request not to teach on Saturdays any longer. ${ }^{52}$ Five years later, Miss Frances Parker obtained a month of holidays in December. Some teachers succeeded in negotiating changes to the school routine, as was the case when the school board agreed to allow any teacher to dispense with afternoon recess in December and January in order to end the school day at 3:30 p.m. instead of the usual 4:00 p.m. "if it would not interfere with the school work."53 The board offered salary increases and bonuses to some teachers in recognition of their teaching skills. For instance, trustees offered Miss W $\$ 70$ a month "if she continues to give satisfaction" until the end of her term in addition to paying her another $\$ 5$ for September and October. ${ }^{54}$ That it was also trying to avoid a staffing crisis goes without saying since half the complement of teachers had submitted their resignations effective December $31^{\text {st }} 1927 .{ }^{55}$

Table 1 reveals the extent of the problem that the school board confronted both in attracting teachers, as seen in the late start or long holiday breaks of the school term, and in retaining teachers, as seen in school terms when more than one teacher had to be

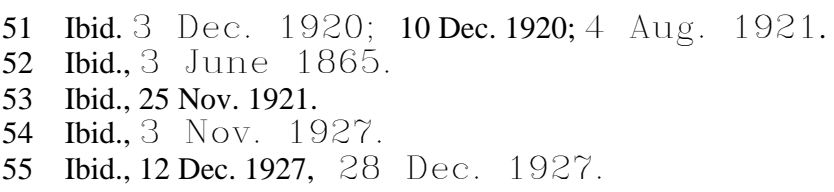


TABLE 1

Multiple Teachers and Late Starts in Lochaber Schools, 1903-45

\begin{tabular}{|c|c|c|c|c|}
\hline TERM & $\begin{array}{l}\text { SCHOOL \#1 (Thurso } \\
\text { Village) }\end{array}$ & $\begin{array}{l}\text { SCHOOL \#2 (Lochaber } \\
\text { Bay) }\end{array}$ & $\begin{array}{l}\text { SCHOOL \#3 (Gore of } \\
\text { Lochaber) }\end{array}$ & $\begin{array}{l}\text { SCHOOL \#4 (Silver } \\
\text { Creek) }\end{array}$ \\
\hline $1903-4$ & 1 teacher & 1 teacher & 1 teacher & $\begin{array}{l}2 \text { teachers } \\
\text { no school in Oct \& Jan }\end{array}$ \\
\hline 1908-9 & 2 teachers & $\begin{array}{l}2 \text { teachers } \\
\text { long Easter break } \\
\text { (teacher resigned) }\end{array}$ & 1 teacher & 1 teacher \\
\hline $1909-10$ & 1 teacher & $\begin{array}{l}\text { school of } 78 \text { days } 1 \text { st } \\
\text { term }\end{array}$ & 1 teacher & 1 teacher \\
\hline $1910-11$ & 2 teachers & 1 teacher & 1 teacher & 1 teacher \\
\hline 1911-12 & 1 teacher & $\begin{array}{l}\text { term started } 6 \text { Nov and } \\
\text { no school } 20 \text { Dec-22 Jan }\end{array}$ & 1 teacher & 1 teacher \\
\hline $1912-13$ & 1 teacher & term started 9 Dec & $\begin{array}{l}1 \text { teacher } 4 \text { mo. only } 2 \\
\text { pupils }\end{array}$ & 1 teacher \\
\hline 1913-14 & 3 teachers & 1 teacher & 1 teacher & 1 teacher \\
\hline $1915-16$ & 1 teacher & 1 teacher & 2 teachers & 1 teacher \\
\hline 1916-17 & 1 teacher & term started 18 Sept & school closed & 2 teachers \\
\hline $1917-18$ & 1 teacher & 1 teacher & $\begin{array}{l}2 \text { teachers } \\
\text { no school in Jan \& Feb } \\
\text { (teacher ill) }\end{array}$ & $\begin{array}{l}1 \text { teacher who taught } 9 \frac{1}{2} 2 \\
\text { mo. }\end{array}$ \\
\hline 1918-19 & 1 teacher & $\begin{array}{l}\text { no school } 20 \text { Dec-16 Jan } \\
\text { influenza }\end{array}$ & $\begin{array}{l}\text { school closed from Sept- } \\
\text { Dec }\end{array}$ & 1 teacher \\
\hline
\end{tabular}




\begin{tabular}{|c|c|c|c|c|}
\hline $1919-20$ & 2 teachers & 1 teacher & school closed & 2 teachers \\
\hline $1920-21$ & 1 teacher & $\begin{array}{l}2 \text { teachers \&term started } \\
13 \text { Sept }\end{array}$ & $\begin{array}{l}\text { school closed from Sept- } \\
\text { Dec }\end{array}$ & 1 teacher \\
\hline $1921-22$ & 1 teacher & $\begin{array}{l}\text { no school } 5 \text { Dec-4 Jan } \\
\text { scarlet fever }\end{array}$ & $\begin{array}{l}\text { school closed from Sept- } \\
\text { Dec }\end{array}$ & 1 teacher \\
\hline $1922-23$ & term started 1 Oct & $\begin{array}{l}\text { no school for } 3 \mathrm{wk} \text {. } \\
\text { scarlet fever }\end{array}$ & 1 teacher & 2 teachers \\
\hline $1923-24$ & 1 teacher & 2 teachers & 1 teacher & 2 teachers \\
\hline $1924-25$ & 1 teacher & 1 teacher & 1 teacher & $\begin{array}{l}\text { school closed } 31 \text { May } \\
\text { (teacher ill) }\end{array}$ \\
\hline $1925-26$ & 2 teachers & 1 teacher & 1 teacher & 2 teachers \\
\hline $1926-27$ & 4 teachers & 2 teachers & 2 teachers & 1 teacher \\
\hline $1928-29$ & 1 teacher & school reopened 21 Jan & 1 teacher & 1 teacher \\
\hline 1931-32 & 1 teacher & 1 teacher & term started 1 Nov & 2 teachers \\
\hline $1932-33$ & no school Dec & 2 teachers & 2 teachers & term started 3 Oct \\
\hline 1940-41 & 1 teacher & 1 teacher & term started 19 Sept & 1 teacher \\
\hline $1941-42$ & 1 teacher & 1 teacher & $\begin{array}{l}2 \text { teachers school closed } \\
25 \text { May whooping cough }\end{array}$ & $\begin{array}{l}2 \text { teachers \& no school } \\
18 \text { Nov-2 Feb }\end{array}$ \\
\hline $1945-46$ & 1 teacher & 1 teacher & 1 teacher & term started 1 Oct \\
\hline
\end{tabular}

Compiled from the Reports of the School Trustees, 1903-32, 1940-46; School Journals, 1932-46; Minutes of the School Board, 1903-45. 
employed. Over a twenty-five-year period, trustees had to hire several teachers in the same term in school \#1 - a quarter (24 per cent) of the time - but few actual school days (8 per cent) were lost because they succeeded in securing teachers before the new school term started. In both schools \#2 and \#3, only a fifth (20 per cent) of the terms were affected by resignations of teachers before the end of their contracts but the trustees were less efficient in recruiting teachers to take these schools, resulting in late starts and longer holiday periods in a quarter (24 per cent) of the terms in school number \#3 and more often (28 per cent) in school \#2. This same school \#2 was closed periodically between 1916 and 1921 and the children sent to the Lochaber Bay school. Rotating schools and shortening school terms were just some of the measures school boards instituted, argues Little, to deal with insufficient operating budgets $^{56}$ and, in the case of Lochaber and Gore, to solve teacher shortages. ${ }^{57}$ The Silver Creek school was especially problematic. Trustees had to replace teachers in more than a third (36 per cent) of the terms in addition to a fifth (20 per cent) of them starting late or involving extended holiday breaks.

The challenge to school boards of hiring suitable teachers was universal to rural and remote regions across Canada. In Northern Ontario, for example, historian John Abbott found that school board trustees and commissioners resorted to unqualified teachers during periods of teacher shortages. They engaged teachers who came from more populated regions of the province, in this case Southern Ontario, who were leaving home for the first time to begin their teaching career. ${ }^{58}$ The transitory nature of teacher employment created what Abbott calls a gender discourse which equated female teachers with transiency and unreliability and male inspectors with management and a commitment to teaching as a profession. Men were also seen as more capable of providing discipline and advanced knowledge. ${ }^{59}$ Certainly, Outaouais

\footnotetext{
56 Little, Crofters and Habitants, 235.

57 In July 1930, the secretary treasurer advertised for teachers at the following salaries: The school board would pay the Thurso village teacher \$650 and the Lochaber Bay teacher $\$ 600$ both for 10 months of teaching, but the Gore of Lochaber teacher would be paid $\$ 45$ a month for 9 months beginning October $10^{\text {th }}$. In the event that it could not find a teacher for that salary, then the Gore of Lochaber teacher would be offered $\$ 50$ a month for 8 months, the school term to start November $1^{\text {st }}$ (AWQSB, Box 6, File 6.9, Minutes, 15 July 1930).

58 John Abbott, “Accomplishing 'a Man’s Task': Rural Women Teachers, Male Culture, and the School Inspectorate in Turn-of-the-Century Ontario,” Ontario History 78, 4 (1986): 320-21.

59 Ibid., 327.
} 
inspector Bolton McGrath was imbued with this same ethos when he argued against the feminization of teaching:

In this province we change too often, our common schools are largely in charge of female teachers who naturally prefer a home to the precarious calling of teaching, and, as a consequence, we have too many novices in the charge of schools, who, I regret to say, in some cases are not teachers. ${ }^{60}$

To counter rural teacher transiency, school inspectors, who were critical of the decentralized power of the system of education, proposed a number of measures which would ultimately strengthen the authority of the department of education vis-à-vis the school boards. They recommended that the government establish a minimum salary for all Quebec teachers to help school boards in rural areas secure more competent teachers. Inspectors also blamed school boards for being miserly at the expense of their pupils by refusing to increase school taxes out of fear of alienating the more prosperous residents in the municipality who were uninterested in local schools. McGrath charged that "the class in easy circumstances are not interested in promoting the success of elementary schools since they send their children to 'superior educational institutions' in the cities nor are they receptive to paying higher school taxes.” He proposed that the government be given the power to remove school board members and secretarytreasurers who failed to fulfil their mandates effectively. ${ }^{61}$ Lochaber and Gore proved that McGrath was at least partially wrong. Children of the local elite attended the same schools as their poorer neighbours. Take the example of Dr. Peter MacLaughlan Jr. Born in Lochaber Bay, he attended elementary school there, pursued secondary education at Rockland High School across the river in Ontario and at Albert College in Belleville, and received his post-secondary education at Queen's University, where he graduated with a medical degree. ${ }^{62}$ There was, however, tension between the ratepayers of the more affluent districts and those of the poorest. Ironically, when the school board set the mill rate in 1914, the two most affluent districts, Thurso and Lochaber Bay, paid 5 mills and 31/2 mills respectively, while the most impoverished, Gore of Lochaber, paid 3 mills and Silver

60 Inspector's Report to the Minister of Public Instruction, 1880-81.

61 Inspector's Report to the Minister of Public Instruction, 1868-69.

62 Buckingham Post, 19 July 1918. 
Creek paid 5 mills. Thus, the board levied the same mill rate for Thurso and Silver Creek. ${ }^{63}$ School inspectors also recommended that school boards encourage local students to become teachers. For instance, a number of rural school boards in the Eastern Townships offered scholarships to local students who were accepted into teacher training at Macdonald College or Bishops University. In the Lochaber and Gore district, it would not be until the 1930s when trustees courted two local women, the Misses Nesbitt and McLachlan, both teachers-in-training at Macdonald College, for future teaching positions. Trustees granted them permission to teach in any of the Lochaber schools the first week of January. ${ }^{64}$

Budgetary constraints affected the physical state of the schoolhouses, which only exaggerated staffing problems, especially if the board wanted to rehire specific teachers. Since trustees had little money to maintain and repair their schools, resulting in chronic neglect of the buildings, they had an even greater job trying to convince teachers to renew their contracts at the completion of the school term. Despite the idealization of one-room schoolhouses in popular literature, the rudimentary nature of the teacher's work site was demoralizing. All of the facilities operated without central heating, electricity, or indoor plumbing. The teacher and her pupils hauled water from either the nearest farmhouse or stream, carried and stacked wood each day, taught and studied in drafty, cold school buildings heated with a single wood-burning stove, and used an outdoor latrine. The pathway to the outhouse at the Thurso school was in such poor condition that the school inspector complained to the school board that it was impassable in wet weather. Five months later, after the trail had been "repaired," pupils were still getting their feet wet going to and fro. ${ }^{65}$ Unlike some rural school boards such as those in the Eastern Townships with a better tax base, able to attend promptly to repairs, the Lochaber and Gore board's primitive structures deteriorated through neglect. These conditions drew the ire of the community. Over the eighty years of this study, trustees, parents, inspectors, and teachers regularly discussed the poor state of the school buildings and urged each other to act. The school board itself was not immune to parental criticism. In 1904, ratepayers at Lochaber

63 AWQSB, Box 6, File 6.9, Minutes, 26 Sept. 1914.

64 Ibid., 27 Dec. 1932.

65 AWQSB, Box 23, File 23.13, Lochaber \& Gore Permanent Record, Public Schools, Province of Quebec, 1920-51, 31 May 1929, 18 Oct. 1929. 
Bay were so contemptuous of their elected trustee that a citizen announced to the Buckingham Post that if nothing was done to improve the community school and he did not do his job better, a petition would be circulated asking for his resignation. ${ }^{66}$

To avoid raising the mill rate, Lochaber and Gore trustees sought other ways to pay for school repairs. In 1928 they decided to pool the resources of all four school districts in order to refurbish school buildings. ${ }^{67}$ Thurso ratepayers, imbued with what Little designates "entrenched localism,"68 reacted strongly to this move. From their perspective, they alone controlled the school and its revenues and for these reasons objected to financing school repairs in the other three districts precisely at a time when their own school was crumbling and needed to be replaced. Fed up with the inequality of these arrangements, they petitioned the Superintendent of Education for a separate school board in addition to a new village schoolhouse. Petitioners pointed out that teachers refused to stay beyond their ten-month term because of the chronic dilapidated state of the school. "Last term we had an excellent teacher but she found that the location and condition was not the proper place to have children and would not sign for another year unless some other arrangements were made."69 To reach the schoolhouse, the teacher and her pupils walked along a trail through a wooded area before climbing a hill that was more than thirty feet of sheer rock. ${ }^{70}$ The petition was ineffective. While Thurso ratepayers withdrew their request for a separate school board, they continued to demand a new schoolhouse. Thirteen years later, thirty students still attended the same seventy-year-old Thurso Village schoolhouse even though a Department of Health sanitary engineer had recently condemned it as unfit for habitation.

There is no cellar; the ground floor is only a couple feet over the level of the ground, i.e. on a rock surface. There is no current water in the school. The children have to carry water from a neighbour; they use two outside dry privies set also on the rocky formation. The ground floor of the present class-

\footnotetext{
66 Buckingham Post, 5 Feb. 1904.

67 Ibid., 28 May 1928.

68 See Little, "Labouring in a Great Cause," 97, and "School Reform and Community Control,” 159.

69 Buckingham Historical Society, Report on the Protestant School Situation, Municipality of Thurso, 26 Sept. 1929.

70 Buckingham Historical Society, Correspondence between J.C. Sutherland and G.W. Hamilton, 27 Apr. 1931.
} 
room and the attic floor have heaved; the stairs are unsafe and it has been necessary to anchor at both ends 3 or 4 steel bars through the two longitudinal walls in order to keep them from opening up. ${ }^{71}$

Whatever sense of entitlement the local elite may have harboured about building a new school, the project failed to elicit the support of the school trustees, whose responsibilities were broader. The state of rural school buildings had been a subject of intense discussion amongst education officials long before this. Inspectors were so acrimonious toward rural school boards about the decrepit condition of their schools that the Minister of Public Instruction extolled the benefits of more attractive schoolhouses:

If now the schoolhouse be spacious and airy, if the furniture, desks and seats are appropriate, if the garden be well kept, the children will be delighted with school; instead of inventing excuses of absence, they will love to attend regularly every day, and we shall witness, at length, the disappearance of the grand complaint made by inspectors in all their reports irregular attendance in the country schools. ${ }^{72}$

Notwithstanding his rather superficial correlation between rundown schools and attendance, the conditions of the local schoolhouse were not very different from those at home. The township of Lochaber and Gore was, like other rural communities, poor. A survey by the federal government in 1931 reveals that the percentage of farms with running water and electricity in Papineau County, which included Lochaber and Gore, was far below the average of rural Quebec. ${ }^{73}$

The school board did apply to the Department of Education for special grants to finance the much needed repairs. But even when the department provided funding to replace a particular school, the Lochaber and Gore board did not always act until officials threatened to cut off all grants. In 1939, exasperated with the trustees who had not replaced the sixty-five-year-old log schoolhouse at Silver Creek two years after they had been authorized to do so, Dr. Percival, then director of Protestant

71 AWQSB, Correspondence between Dr. Leo Lynch and Romeo Mondello, 24 Sept. 1942.

72 The Superintendent's Report, 1879-80.

73 Gaffield et al., History of the Outaouais, 335-36. 
education, decided to withhold the provincial annual grant until a new school was erected. Although the board argued that the district's revenues were insufficient to support a new school, Dr. Percival countered that "this action is not in accordance with the principles of democracy or the school law." He was prepared, however, to consider new ways to reduce the costs, which included building a cheaper school. ${ }^{74}$ The following year, the teacher and children moved into a newly constructed schoolhouse. ${ }^{75}$

\section{Teachers}

Teachers confronted a host of problems when they arrived at their schoolhouses for the first time: dilapidated buildings, parents frustrated by the appearance of another new and inexperienced teacher, and an unfamiliar environment marked by desolation and loneliness. Three of the four Lochaber and Gore schoolhouses were situated on isolated rural roads surrounded by fields or forest and distant from the closest farms. Teachers also had to contend with sporadic school attendance. Without a district conveyance system, children had difficulty getting to school because of winter storms, the combination of spring rains and poor roads, and inadequate clothing. Lochaber and Gore parents, like their counterparts in Winslow, were often too impoverished to afford suitable winter clothing so that their children could attend school. ${ }^{76}$ Similarly, farmers needed their children at home to work during the annual planting and harvest seasons. ${ }^{77}$ Notwithstanding the very real conflict between what Bruce Curtis refers to as the seasonal needs of agricultural production and school time, ${ }^{78}$ Quebec's education officials blamed poor school attendance on parents' lack of interest in their children's education or in the affairs of the school. Epidemics also played havoc with school attendance.

74 AWQSB, Correspondence between Dr. Percival and Inspector King, 20 Sept. 1939. 75 The new one-room building was an improvement over the older schoolhouse. Willard Smith, who had attended the two schools as a child, notes that the 1940 school had a full basement, a wood furnace, and indoor washrooms. Because there was no electricity or running water, students continued to carry water from the nearby creek. See Smith, Silver Creek: The Centre of the World, 61-62.

76 Little, Crofters and Habitants, 235-36.

77 On this subject see Chad Gaffield and Gérard Bouchard, "Literacy, Schooling, and Family Reproduction in Rural Ontario and Quebec," Historical Studies in Education 1, 2(1989)201-18;Chad Gaffield, Children, Schooling and Family Reproduction in Nineteenth-Century Ontario, CHR 72, 2 (1991): 157-91.

78 Curtis, Building the Educational State, 184-85. 
Sometimes the school was closed for weeks at a time when outbreaks of influenza and childhood illnesses such as whooping cough ravaged the district. Moreover, teachers were exposed to the same diseases as their students and just as vulnerable to getting ill, as Miss P discovered. Trustees called a special meeting to discuss why the Gore of Lochaber school had been closed and the teacher went home without their permission. They ascertained that the children, who had been ill with whooping cough, had been out of school beyond the fourteen-day quarantine imposed by law for this disease. When the chairman finally contacted Miss P, she told him that she too had come down with whooping cough and could not return to the district until she was fit to travel. ${ }^{79}$ Sporadic school attendance meant that a teacher's work was constantly interrupted: some students were behind the others and needed more attention to catch up; they required her to revise her daily lessons repeatedly; they had difficulty following the curriculum. She faced criticism on these issues from inspectors, trustees, and parents alike.

There is a growing Canadian literature about rural schools which speaks to some of the problems that young, unmarried women faced in isolated rural areas in Quebec and elsewhere, especially in Ontario. ${ }^{80}$ Teachers are often viewed as victims of the tyranny of both school board commissioners and trustees who did not renew teaching contracts for flimsy excuses (if one was even offered), and of communities which were suspicious of outsiders. An examination of Lochaber and Gore's Anglo-Protestant community reveals that its relations with teachers varied, just as attitudes and personalities did. That so many teachers remained a short period of time at the schools - so much so that parents had

79 AWQSB, Box 6, File 6.9, Minutes, 27 May 1942.

80 For Quebec, see for example Jacques Dorion, Les Ecoles de rang au Québec (Montreal: Editions de l'homme, 1979); Marta Danylewycz and Alison Prentice, "Teachers' Work: Changing Patterns and Perceptions in the Emerging School Systems of Nineteenth- and Early Twentieth-Century Central Canada,” Labour/Le Travail 17 (1986): 59-80; Gaffield and Bouchard, "Literacy, Schooling, and Family Reproduction in Rural Ontario and Quebec"; Little, "Education and Local Government”; Dufour, Tous à l'école; and Charland, L'entreprise éducative au Québec. For elsewhere, see Houston and Prentice, Schooling and Scholars; and on gender and teaching, see Alison Prentice, "The Feminization of Teaching," in The Neglected Majority: Essays in Canadian Women's History, ed. Susan Mann Trofimenkoff and Alison Prentice (Toronto: McClelland \& Stewart, 1981); Abbott, “Accomplishing 'a Man's Task'.” On rural schooling elsewhere, see Cochrane, The One-Room School in Canada; J. Donald Wilson and Paul J. Stortz, "May the Lord Have Mercy on You: The Rural School Problem in British Columbia in the 1920s,” BC Studies 79 (1988): 24-58; Jean Barman et al., eds., Children, Teachers and Schools in the History of British Columbia (Calgary: Detselig Enterprises, 1995); and Paul Axelrod, The Promise of Schooling: Education in Canada, 1800-1914 (Toronto: University of Toronto Press, 1997). 
little opportunity to get to know them - aggravated an already difficult situation. Others were held in high esteem; a few even stayed for a number of years. Parents sometimes petitioned the school board to request that trustees engage a respected teacher. For example, Lochaber Bay ratepayers sent a petition to the trustees asking that Miss Maggie McLean be rehired to teach at their school and at the same salary. ${ }^{81}$ In other cases, a teacher's resignation caused considerable sadness. A case in point was Miss Grace Simpson. She taught at the Lochaber Bay School for three years before moving to Ormstown to take care of her ailing mother. A year later Miss Simpson accepted a position at the Ormstown Academy and quickly rose up through the ranks. At the time of her premature death from pneumonia, fifteen years after leaving Lochaber and Gore, she was the French specialist at the school. Grace Simpson was a prototype of the "lady teacher" and her relationship with the school trustees and parents represented an ideal partnership. While toiling under adverse working conditions, she exemplified dedication, accommodation, and amicability both in and outside the schoolhouse.

Teachers faced high expectations from the communities where they taught. They had to be, according to J. Donald Wilson and Paul Stortz, simultaneously role models, caretakers, leaders in the community, representatives of the provincial education system, and educators. ${ }^{82}$ Quebec rural teachers usually had the added burden of collecting the monthly school fees. In Lochaber and Gore, many were put in the impossible position of having to meet unattainable goals established by the community without the resources to succeed. Beyond this arduous task for one so young and inexperienced, a rural teacher, especially if female, lived her personal and professional life in a fish bowl, her teaching abilities and behaviour carefully scrutinized by those around her. That the teacher boarded with a farming family chosen not by her but by the community only added to public scrutiny. Whether the boarding house was to her liking or not was inconsequential: she had to adjust even if it meant a dramatic change in her accustomed living conditions. Since a teacher was expected to be an example to her pupils and to the community at large, she had to be careful about the friendships she established, taking care not to become a subject of gossip. If she fitted in, she was accorded a degree of respect and status which had a direct bearing on her classroom experience.

81 AWQSB, Box 6, File 6.8, Minutes, 10 Aug. 1889.

82 Wilson and Stortz, "May the Lord Have Mercy on You," 31. 
Establishing good relationships with the community served to reduce the loneliness, promote acceptance, and maintain her authority in the classroom. And above all, she had to be a skilled diplomat in her dealings with the school board and parents. ${ }^{83}$

Hired without an interview but on the strength of their application in conjunction with the needs of the school board, teachers often had little idea what they were getting into when they accepted the position. Even teachers who came from other rural areas of the province to teach in Lochaber and Gore could not have anticipated some of the worst conditions that awaited them, and that created a daunting task for the most experienced and mature teacher. Some were simply unsuited to teach in rural Quebec. Miss M, whom we met at the beginning of the article, had difficulty organizing her daily teaching schedule, let alone dealing with a multi-graded classroom of pupils. When Miss G allegedly had "shown incapacity and negligence in the performance of her duties," ${ }^{84}$ she was asked to resign her position at the Gore of Lochaber school before the end of term. Trustees relented in all likelihood only because they realized it would be too difficult to engage another teacher for only a month. Without job security, it was difficult for teachers to control their working conditions such as class size, or to be remunerated adequately. They protested most often by resigning, sometimes contesting the most frank disparities, and occasionally by marrying before the end of their contract, which essentially ended their teaching careers. Six teachers married before completing their contracts. Five of the six reported marriages occurred during World War One, when it was customary for betrothed couples to marry before soldiers went overseas or soon after they returned from their tour of duty. While it is not known if Miss Ruby S who taught at the Gore of Lochaber school actually wedded a soldier, she resigned six months into her contract to get married. ${ }^{85}$ The school board records also show cases of women arranging their replacements with the board before resigning to get married. When Mabel Liths left the Silver Creek School after her wedding, her sister Lucy finished the school term for her. ${ }^{86}$

Teachers objected to the worst features of their workplace although the school board seldom acted on their grievances. A case

83 Ibid., 31-32.

84 AWQSB, Box 6, File 6.9, Minutes, 24 Oct. 1926.

85 AWQSB, Box 23, File 23.9, Reports of the School Trustees, 1903-32, 1915-16.

86 Ibid., 1920-21. 
in point is Mrs. C, who taught at the Silver Creek school. When she requested that certain repairs be made to her school, the trustees responded by refusing to renew her contract unless the inspector gave her a favourable report and the ratepayers of the district agreed to comply with her wishes to repair the building. ${ }^{87}$ They did not and she left. Since it was the responsibility of each of the four districts to maintain its own schoolhouse, the parents' refusal to comply may have also been a consequence of the teacher's assertiveness, which was incongruent with the demeanour expected of her to be ladylike in all matters, including coping with the wretched condition of her school; and it may have been due as well to the added burden it placed on ratepayers to finance the improvements.

Teachers resisted most often by resigning their teaching position. Few teachers stayed for more than one term; most stayed only for the duration of their engagement. Either they did not have their contracts renewed or they resigned at the end of the school year. Some became ill and unable to teach or were unwilling to stay, and terminated their contracts prematurely. Others left during periods of teacher shortages knowing that they could procure better positions elsewhere. As we have already noted in Table I, the 1920s - with a province-wide teachers' shortage - was a particularly difficult period. In the Thurso Village school alone, trustees had to find a replacement three times during the 1926-27 term. One of the substitutes, Miss McMahon, who had just started her teaching career, faced a classroom of 55 pupils spread over seven grades. ${ }^{88}$ That same year the board had to find replacements for teachers in two of its other schools.

Most of the women left to take up teaching in towns and cities, where boards offered better salaries as well as working and living conditions. For many teachers, the experience they gained by working in Lochaber and Gore schools meant that they could seek positions in nearby Ontario with its higher salaries and better working conditions. Even as late as the 1930s, teachers were in the extraordinary situation of having to teach the Ontario, and not the Quebec, school curriculum. That school inspectors were appalled at the presence of an imported course of study and accompanying school books in these Quebec classrooms refutes any idea that the Quebec Protestant school system was merely a subset of the

87 AWQSB, Box 6, File 6.9, Minutes, 28 May 1923.

88 Gatineau Protestant Teachers' Association Centenary Display, History of Education, 35. 
Ontario structure. Ratepayers, especially those who lived in Lochaber Bay, insisted that the school board continue to use Ontario textbooks since "they have given good satisfaction and no injury done to any child." 89 To purchase new ones would have burdened the school board and ultimately the ratepayers with a large expense at a time when a special tax had been applied for school repairs. With the support of parents, trustees stubbornly clung to these texts, despite school inspectors' routine low grading of schools in Lochaber and Gore because of their presence in the classrooms.

The peculiar situation is, that the grades all use the Ontario course of study and also the textbooks of the course. This is of course quite contrary to the law and regulations of the province and should be changed as soon as possible. ${ }^{90}$

The irony of this situation seems to have been lost on the trustees. The teachers' familiarity with the Ontario curriculum held them in good stead when they applied for employment in Ontario schools. Such was the case for Miss Georgia McEachern. She left the Lochaber Bay school to teach in Ontario at Hammond, just across the Ottawa River from the township, and later at Havelock, near Peterborough. ${ }^{91}$

Why, then, did teachers accept positions in rural areas such as Lochaber and Gore? Rural school boards needed large numbers of teachers to work in their schools and despite their preference for experienced ones, they offered the best employment prospects to recent graduates of teachers' education at the McGill Normal School and later Macdonald's College and to alumni of model schools and academies. Teaching gave many of these young women the opportunity to leave home for the first time, to be financially independent, and to work in a respected profession. Kathleen Underwood's study of teachers in the turn-of-the-century American west has a certain resonance with Lochaber and Gore. These women sought work as teachers for a variety of reasons: to contribute to the household economy, to be independent, and to advance their own education. Although they moved from job to job in search of better pay, longer teaching terms, better living and

89 AWQSB, Box 6, File 6.9, Minutes, 9 Jan. 1932.

90 AWQSBBBox23PemmetRecord, Public Schools, Province of Quebec, 1922-40,

2 Oct. 1922.

91 AWQSB, Box 6, File 6.8, Minutes, 15 Mar. 1918, 10 Jan. 1919. 
working conditions, or to be closer or further from home, teachers were committed to their profession. ${ }^{92}$

\section{Parents}

Teachers needed not only the collaboration of the school board to teach effectively but that of the parents as well. This study shows that parents were involved and interested in their children's education. Individual grievances and district petitions about the school board, teachers, and the conditions at particular schools underscore parents' attentiveness to the local schoolhouse. Until recently, historians have characterized parents as apathetic about the quality of their children's education, the suitability of the schoolhouses, and the importance of regular classroom attendance. In Lochaber and Gore, parents, teachers, trustees, and students participated together in school traditions such as the annual Christmas concert and school closing ceremonies. These formal activities provided those attending with an opportunity to celebrate their Anglo-Protestant heritage - thus to reinforce identity and citizenship - as well as offering parents and trustees a window onto the classroom whereby they could judge the teacher's abilities and organizational skills, review school work, and express appreciation to a respected and admired teacher. Parents could also assess the effectiveness of the school board and how their tax dollars were being spent.

They were especially interested in what and how their children were learning at school. Like school trustees, parents often held the teacher responsible for problems at the schoolhouse, whether deserved or not. School board minutes, which serve as a window onto the process of conflict resolution at a local level, indicate that trustees were attentive to these complaints and dealt with most of them in a satisfactory manner. Few of their grievances ended up in correspondence to the Superintendent of Education. Trustees took their complaints seriously, by discussing them at great length at regular school board meetings, by organizing special meetings to review serious charges, and by establishing committees to investigate the most onerous ones. When Silver Creek ratepayers petitioned the school board about a rumour involving "an indecent and immoral act” having occurred between students at lunch time,

92 Kathleen Underwood, "Schoolmarms on the Upper Missouri," Great Plains Quarterly 11 (1991): 227-29. 
the trustees acted immediately. Although details of the incident are unclear, trustees responded to the petition by quickly establishing a committee to look into the matter. Committee members soon discovered that a mother had taken matters into her own hands by going to the school to question the young girl who allegedly had been involved in the incident in front of her peers. They demanded that both the teacher, Miss T, for allowing the interrogation to take place, and the mother, for conducting it, apologize to the girl's father. The incident was further exacerbated when it came to light that Miss T had in fact punished the girl unjustly by expelling her from school even though she had been telling the truth. ${ }^{93}$ The castigation of the teacher did not end here, for the board initially refused to renew her contract at the end of the term. It is also apparent from this particular incident that the board did not want parents to become directly involved in what it considered its jurisdiction at the schools. Trustees informed one mother with a penchant to interfere at the local schoolhouse that if she planned to keep her children in any of the Lochaber and Gore schools, she was to desist from going to the school to speak to the teacher about her grievances. They insisted that she bring any complaints she might have about the schoolteacher to the board. ${ }^{94}$ This intervention served, on the one hand, to protect the teacher from unjust parental criticism, and on the other, to ensure the school board's control over schoolhouse affairs.

Parents voiced other sorts of grievances. Occasionally, they objected to the rehiring of a teacher, as several Silver Creek ratepayers did in August 1906 when they petitioned the school board to express their disappointment with its decision to retain the services of Miss $\mathrm{M}$, who had been teaching at the Silver Creek school. Because the petitioners acted after a May $1^{\text {st }}$ deadline, trustees argued that they could not legally act upon such wishes. ${ }^{95}$ Parents had very definite ideas about what they expected from teachers vis-à-vis skill and competency. In a 1915 petition, ratepayers criticized one teacher's method of instruction and the amount of time she allocated to mathematics.

The board is unanimous [sic] of the opinion that she shall give greater attention to the study of arithmetic and that she use different methods in the way of correcting examples and in

93 AWQSB, Box 6, File 6.9, Minutes,23 Feb. 1922.

94 AWQSB, Box 6, File 6.8, Minutes, 8 Oct. 1912.

95 Ibid., 25 Aug. 1906. 
helping pupils with difficult ones in the way of explaining them the different parts. $^{96}$

While petitions were in themselves difficult to ignore, individual complaints garnered similar attention. The trustees held a special meeting in response to a written grievance by Henry Berndt regarding the teacher's competency at the Gore of Lochaber school. After due consideration of the complaint and Berndt's appearance at the meeting to proffer proof of his complaint, the trustees decided to let Miss G go effective June $1^{\text {st }}$ because "she has shown incapacity and negligence in the performance of her duties."97 Similarly, the board notified Miss $\mathrm{H}$ that it had received two complaints: the first, regarding a lack of discipline in the Thurso school, and the second, that required work was not being done by her students. The trustees directed her to redress these problems. ${ }^{98}$

If teachers appeared to have unrealistic expectations of their students, parents criticized them. Trustees notified Miss B that she "comply with the law as to time given to pupils for recreation during the day and not give lessons that are beyond the ability of the pupils to learn and retain"; at the same time they informed her that her contract would not be renewed at the end of the school term. ${ }^{99}$ Parents complained about the treatment of their children at the hands of the local teacher, as in the case of one father who requested that his son be moved to another school in the municipality. The board granted his request and transferred the student to a different school with the proviso that the new teacher be instructed to pay more attention to the boy. ${ }^{100}$ Obviously parents were aware of what went on in the classroom! The close proximity of their lives provided many opportunities for parents and teachers to meet socially, allowing teachers to bring up specific disciplinary problems with them. According to Silver Creek alumnus and teacher Willard Smith, parents often responded to a teacher's punishment of their children with, "You probably deserved it!"101 However, if parents considered the castigation to be unreasonable, they complained to trustees. Similarly, the board supported teachers who had difficulties with particular students whose

96 AWQSB, Box 6, File 6.9, Minutes, 20 Feb. 1915.

97 Ibid., 22 Apr. 1926.

98 AWQSB, Box 6, File 6.8, Minutes, 23 Feb. 1929.

99 AWQSB, Box 6, File 6.9, Minutes, 28 April 1922.

100 Ibid., 20 Feb. 1915.

101 Smith, Silver Creek: The Centre of the World, 63. 
behaviour was usually well known in this tight-knit community. When Miss Stewart complained about a pupil in the Lochaber Bay school, the trustees counselled her to follow the pertinent regulations printed in the school journal and to expel the child from school if necessary. ${ }^{102}$

Attuned to the scholastic needs of their children, parents initiated changes at the schoolhouse. They asked the school board to introduce higher grades, aware that it would result in added personal costs, and often obtained the consent of the teacher beforehand. In 1926, for instance, parents of children attending Lochaber Bay school asked the trustees to have grade eight taught at the school; they buttressed their request by having elicited the consent of the teacher to add the grade to her already heavy workload. The board acquiesced on the following conditions: the extra class would not interfere with the lessons of the other grades, the teacher was willing, and the parents were amenable to augmenting the teacher's salary for this added task and to purchasing the necessary books. The board appointed trustee McCallum and the secretary-treasurer to arrange a meeting of the parents and teacher to send the petition to the Superintendent of Public Instruction for his formal consent. ${ }^{103}$ This act speaks directly to the parents' belief in the importance of education and to their confidence in the local teacher.

While parents were swift to complain about teachers, so too were they quick to express their gratitude to those they appreciated and valued. As already noted, they petitioned the school board to rehire certain teachers. Parents also praised teachers to whom they presented a variety of gifts from food to jewellery at Christmas or when they left the community. After Grace Simpson resigned from the Lochaber Bay school, having taught there for "three years in succession,"she was given a farewell banquet at the Lamb home attended by forty of the town's citizens. They sang, played games, dined, and made speeches attesting to her worthiness as a teacher and a friend. At the end of the evening the chairman of the school board, A.P. MacLaughlan, presented Miss Simpson with a gold ring set with pearls and a gold bracelet as a token of the community's esteem for her and for her teaching efforts:

It serves to prove that you have won the respect of your pupils and the confidence of their parents. After having rendered

102 AWQSB, Box 6, File 6.9, Minutes, 28 Sept. 1931.

103 Ibid., 3 Sept. 1926. 
your services for the past three years in the capacity of teacher, we do not hear one word of adverse criticism, only expressed commendation and approval. It is a record that you have every reason to be proud of. We know of no words which could so eloquently portray your fitness for the high calling which you have chosen in life. ${ }^{104}$

The report of her death in the Buckingham Post ${ }^{105}$ fifteen years after leaving Lochaber Bay shows the respect that the community still held for her.

The complaint of parents about the quality of education their children received, teacher competence, and the condition of the schools, their requests for the inclusion of higher grades in the school curriculum, and their warm relationships with certain teachers contradict the criticism levelled at parents by inspectors who claimed that parental apathy in education matters contributed to the poor progress of scholars. By the 1930s the Women's Institute was firmly ensconced in Lochaber Bay; with its keen interest in local education, it would serve as a precursor to the Home and School Association, established twenty years later.

\section{Conclusion}

This microstudy of Gore and Lochaber reveals that relationships between the school board, teachers, and parents were mired in complexity and ambiguity. Constrained by a narrow tax base, the school board operated the schools at the teachers' expense. By hiring young, inexperienced women, paying low salaries, and resorting to unqualified female teachers to teach in run-down schools, the boards simply reinforced teacher transiency, a problem trustees never solved in the period under study. The contours of these gendered relations were replicated over and over again. Handicapped by such a narrow vision, the trustees repeatedly searched for new teachers at the end of each term, and sometimes more often. In this way, stereotypes about women teachers encouraged a gendered discourse equating women with a temporary status in the profession and men with a commitment to it. Averse to increasing the tax rate on an impoverished constituency, the school board simply made do. Trustees

104 Buckingham Post, 14 July 1905.

105 Ibid., 5 Mar. 1920. 
consistently engaged a qualified teacher for the village school and frequently for the Lochaber Bay school, but often resorted to unqualified teachers in the Silver Creek and Gore of Lochaber schools. Class affiliations influenced where they placed qualified teachers.

Parents and trustees often held teachers responsible for whatever happened at the district schoolhouses. In part, frustrated by the turnstile nature of new teaching personnel who were almost always inexperienced and young, and the inconsistency in teaching that followed with so many staff changes, parents questioned their teaching methods, expectations, authority in the classroom, and organizational skills. They valued and praised teachers who, despite the terrible conditions imposed upon them, were able to meet and sometimes exceed parental expectations. Teachers expressed dissatisfaction with their working conditions and salaries by resigning at the end of the school term, by quitting before the completion of their contract, and by complaining to inspectors and to trustees. Few teachers stayed longer than a year. Many who took positions elsewhere continued to pursue their teaching careers in other parts of the province and in other regions of the country.

Notwithstanding the school board's success by war's end in hiring married women from the community to teach, thus creating more constancy in the teaching staff, the board's struggle to maintain their four schools close to their constituency collapsed after the Second World War. To standardize education and reduce costs, the Protestant Committee promoted the benefits of county central boards in certain regions of rural Quebec. This directive greatly affected Protestant school boards, like Lochaber and Gore, which had to contend with a dwindling, scattered anglophone population due to out-migration from the countryside to urban centres. Its protest against this centralization notwithstanding, the dissentient school board lost its fight to maintain control over Protestant education in Lochaber and Gore when it came under the jurisdiction of the Papineau County School Board. By the1950s the four schools had closed and the township's children were transported to the consolidated Thurso Intermediate School in Thurso village. 